\title{
Holocene evolution of Apalachicola Bay, Florida
}

\author{
Lisa E. Osterman • David C. Twichell • \\ Richard Z. Poore
}

Received: 12 January 2009/Accepted: 14 August 2009/Published online: 16 September 2009

(C) US Government 2009

\begin{abstract}
A program of geophysical mapping and vibracoring was conducted to better understand the geologic evolution of Apalachicola Bay. Analyses of the geophysical data and sediment cores along with age control provided by $34 \mathrm{AMS}{ }^{14} \mathrm{C}$ dates on marine shells and wood reveal the following history. As sea level rose in the early Holocene, fluvial deposits filled the Apalachicola River paleochannel, which extended southward under the central part of the bay and seaward across the continental shelf. Sediments to either side of the paleochannel contain abundant wood fragments, with dates documenting that those areas were forested at 8,000 ${ }^{14} \mathrm{C}$ years B.P. As sea level continued to rise, spits formed of headland prodelta deposits. Between $\sim 6,400$ and $\sim 2,500{ }^{14} \mathrm{C}$ years B.P., an Apalachicola prodelta prograded and receded several times across the inner shelf that underlies the western part of the bay. An eastern deltaic lobe was active for a shorter time, between $\sim 5,800$ and $5,100{ }^{14} \mathrm{C}$ years B.P. Estuarine benthic foraminiferal assemblages occurred in the western bay as early as $6,400{ }^{14} \mathrm{C}$ years B.P., and indicate that there was some physical barrier to open-ocean circulation and shelf species established by that time. It is considered that shoals formed in the region of the present barrier islands as the rising sea flooded an interstream divide. Estuarine conditions were established very early in the post-glacial flooding of the bay.
\end{abstract}

L. E. Osterman $(\bowtie) \cdot$ R. Z. Poore

U.S. Geological Survey,

600 Fourth St. South,

St. Petersburg, FL 33701, USA

e-mail: osterman@usgs.gov

D. C. Twichell

U.S. Geological Survey,

384 Woods Hole Rd.,

Woods Hole, MA 02543, USA

\section{Introduction}

The Apalachicola River, located on the mid-Florida panhandle, is the largest river in Florida. The Apalachicola, Chattahoochee, and Flint river system originates in the highlands of Georgia, and is the principal contributor of clastic sediment to the eastern Gulf of Mexico (Doyle and Sparks 1980). At the river's mouth, an active delta progrades into Apalachicola Bay at an average rate of $2.2 \mathrm{~m}$ per year (Donoghue 1993). The estuary is approximately $65 \mathrm{~km}$ long, $2-12 \mathrm{~km}$ wide, and is shielded from the open Gulf by a well-developed, nearly continuous chain of three barrier islands. The three islands, St. George, Little St. George, and St. Vincent, shelter four bays, St. George Sound, East Bay, Apalachicola Bay, and St. Vincent Sound (Fig. 1). Within the bay, water depths range between 1 and $16 \mathrm{~m}$, with an average of $\sim 3 \mathrm{~m}$ water depth (mwd).

Analysis of well borings shows that Holocene clastic sediments of the Apalachicola Bay overlie heavily dissected Pliocene and Pleistocene surfaces (Schnable 1966; Schnable and Goodell 1968). Seismic surveys demonstrate that the Apalachicola River incised paleovalleys across the continental shelf during Pleistocene glacial sea-level lowstands (Donoghue 1992, 1993; McKeown et al. 2004). Incised channels occur from 5 to $40 \mathrm{~m}$ below sea level (mbsl), and provide evidence of multiple transgressive and regressive cycles during the Pleistocene (Donoghue 1992, 1993). During the last sea-level transgression, the incised valleys were filled by fluvial, then estuarine, deposits, which spread across much of the bay during the late Holocene (Schnable and Goodell 1968).

The shape of the Apalachicola Bay region itself prior to flooding during the late Holocene can be reconstructed from available well and seismic data. Measurements of depth to the Pleistocene surface were acquired during 


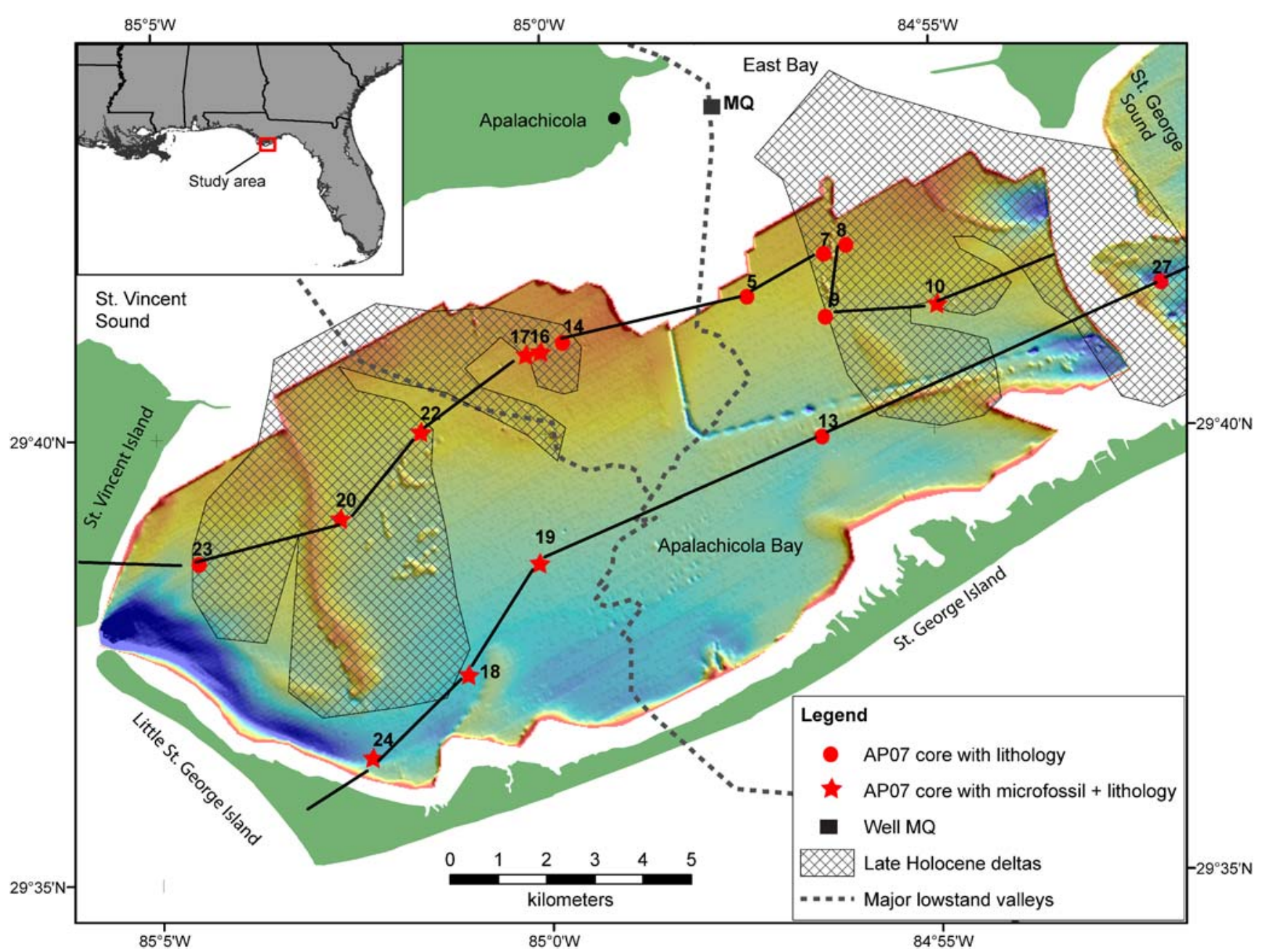

Fig. 1 Locations of vibracores in Apalachicola Bay, Florida, used in this study. The paleoenvironmental interpretation of the eight cores (red stars) is shown in Fig. 2. A stratigraphic correlation of all 16 cores is shown in the northern and southern transects of Fig. 3. The location of the lowstand valley (dashed line) is based on the seismic-survey work for this study and Donoghue (1993). The hatched pattern indicates the extent and distribution of late Holocene sandy deltaic deposits

Previous studies indicate that estuarine conditions in Apalachicola Bay began after the formation of the offshore barrier islands 4,500 to 3,000 years B.P. (Stapor 1973, 1975; Donoghue and White 1995; Forrest 2007; López and Rink 2008). Timing of establishment of the barrier islands and estuarine conditions is of interest because oysters thrive in the shallow protected water of the present Apalachicola Bay. The bay is the site of the largest oyster fishery in Florida (Whitfield and Beaumariage 1977). To understand the geologic evolution of Apalachicola Bay better, as it became linked to the oyster fishery, a program of geophysical mapping was followed by sedimentological and microfaunal analyses of vibracores.

Benthic foraminifers in the Gulf of Mexico have been well studied. Culver and Buzas (1983) summarized the largescale species distributions reported in earlier works (e.g., Phleger and Parker 1951; Bandy 1954; Parker 1954). Applicable smaller-scale species distributions are discussed 
in Phleger (1960), Otvos (1985), and Osterman (2003). The shallowest marine environments consist of low-diversity assemblages of agglutinated foraminifera along with Ammonia and Elphidium. As salinity increases, so do diversity and the percentage of calcareous species. Specifically, marginalmarine assemblages consist of $100 \%$ agglutinated species, whereas in brackish, shallow-water, lagoonal, and estuarine environments the foraminiferal assemblages consist of progressively more calcareous genera, including Ammonia, Elphidium, and Quinqueloculina, and fewer agglutinated species. The inner-shelf environment is characterized by increasingly diverse assemblages of additional species of the above genera, along with Hanzawaia, Haynesina, Protononion, and various Miliolaceans. Outer-shelf assemblages are most diverse and include all of the above, in addition to Buccella, Bulimina, Brizalina, and Cibicides.

\section{Methods}

Geophysical survey and coring

A detailed geophysical mapping effort was conducted in 2005 and 2006 (Twichell et al. 2007). Initial analyses of the high-resolution seismic profiles were used to design a vibracoring program for the summer of 2007. Cores were collected at 24 sites in the Apalachicola Bay and St. George Sound part of the estuary, using a Rossfelder electric vibracorer with a $6.1-\mathrm{m}$ aluminum barrel deployed from the U.S. Geological Survey (USGS) R/V G.K. Gilbert. Core sites included in this study are shown on Fig. 1 and listed in Table 1. The cores were split, described visually, and selected cores were sampled for radiocarbon dating, textural, and faunal analysis.

\section{Dating}

Chronology for the cores is provided by $34 \mathrm{AMS}{ }^{14} \mathrm{C}$ dates (Table 2). Wood and shell samples were converted to graphite targets at the USGS in Reston, VA. The AMS ${ }^{14} \mathrm{C}$ ages were determined at the Center for Accelerator Mass Spectrometry, Lawrence Livermore National Laboratory in Livermore, CA. Quoted ages are in radiocarbon years (B.P.) using the standard Libby half-life of 5,568 years. The ${ }^{14} \mathrm{C}$ dates on marine shells (Table 2) do not include a reservoir correction.

\section{Foraminifers}

Microfossils were examined in 98 samples in eight vibracores. Sediments were processed without additional drying. Sediment was placed in a beaker containing water with a small amount of 5\% Calgon solution, and agitated for less than $60 \mathrm{~min}$. Fines were removed by washing the samples over a $63-\mu \mathrm{m}$ sieve, and the larger residue was placed in a low-temperature oven to dry $\left(<60^{\circ} \mathrm{C}\right)$. The dried fraction was sieved at $125 \mu \mathrm{m}$, and split as necessary using a microsplitter to obtain approximately $200 \pm 100$ specimens. Foraminifers were picked from the sample, placed on a glued 60-square micropalentological slide, sorted, and

Table 1 Location of cores

\begin{tabular}{|c|c|c|c|c|c|}
\hline Core & Latitude (N) & Longitude (W) & $\begin{array}{l}\text { Water } \\
\text { depth }(\mathrm{m})\end{array}$ & $\begin{array}{l}\text { Core } \\
\text { length }(\mathrm{cm})\end{array}$ & Location \\
\hline AP07-05 & $29^{\circ} 41.514^{\prime}$ & $84^{\circ} 57.325^{\prime}$ & 2.9 & 460 & $\begin{array}{l}\text { Paleo-Apalachicola } \\
\text { channel }\end{array}$ \\
\hline AP07-07 & $29^{\circ} 41.972^{\prime}$ & $84^{\circ} 56.373^{\prime}$ & 2.7 & 507 & Norman's Bar North \\
\hline AP07-08 & $29^{\circ} 41.962^{\prime}$ & $84^{\circ} 56.372^{\prime}$ & 2.7 & 542 & Norman's Bar North \\
\hline АР07-09 & $29^{\circ} 40.993^{\prime}$ & $84^{\circ} 55.874^{\prime}$ & 2.7 & 533 & Norman's Bar South \\
\hline AP07-10 & $29^{\circ} 41.363^{\prime}$ & $84^{\circ} 54.970^{\prime}$ & 3.0 & 542 & East of Norman's Bar \\
\hline AP07-13 & $29^{\circ} 39.921^{\prime}$ & $84^{\circ} 56.386^{\prime}$ & 3.5 & 521 & Shoreward of Cedar Point \\
\hline AP07-14 & $29^{\circ} 41.043^{\prime}$ & $84^{\circ} 59.735^{\prime}$ & 2.2 & 528 & Sugar Lumps Bar \\
\hline AP07-16 & $29^{\circ} 40.871^{\prime}$ & $85^{\circ} 00.076^{\prime}$ & 2.0 & 472 & Sugar Lumps Bar \\
\hline AP07-17 & $29^{\circ} 40.872^{\prime}$ & $85^{\circ} 00.170^{\prime}$ & 2.2 & 480 & Sugar Lumps Bar \\
\hline AP07-18 & $29^{\circ} 40.873^{\prime}$ & $85^{\circ} 00.935^{\prime}$ & 3.7 & 427 & Higgins Shoal \\
\hline AP07-19 & $29^{\circ} 40.874^{\prime}$ & $85^{\circ} 00.036^{\prime}$ & 3.5 & 509 & Edge of paleochannel \\
\hline AP07-20 & $29^{\circ} 40.875^{\prime}$ & $85^{\circ} 02.437^{\prime}$ & 3.0 & 558 & St. Vincent Bar \\
\hline AP07-22 & $29^{\circ} 40.876^{\prime}$ & $85^{\circ} 01.491^{\prime}$ & 2.7 & 513 & West Lumps Bar \\
\hline AP07-23 & $29^{\circ} 40.877^{\prime}$ & $85^{\circ} 04.445^{\prime}$ & 3.2 & 518 & Near St. Vincent Island \\
\hline AP07-24 & $29^{\circ} 40.878^{\prime}$ & $85^{\circ} 02.170^{\prime}$ & 3.7 & 544 & $\begin{array}{l}\text { Back of Little St. } \\
\text { George Island }\end{array}$ \\
\hline AP07-27 & $29^{\circ} 40.879^{\prime}$ & $84^{\circ} 52.075^{\prime}$ & 3.5 & 467 & East side of Hotel Bar \\
\hline
\end{tabular}


Table 2 Radiocarbon dates (shells date is on more than one valve, shell date is on a single valve)

\begin{tabular}{|c|c|c|c|c|c|}
\hline & Core and depth & Material & $\delta^{13} \mathrm{C}$ & ${ }^{14} \mathrm{C}$ Age & \pm \\
\hline 1 & APP05 177-178 cm & Wood & -25 & 2,940 & 35 \\
\hline 2 & APP05 285-287 cm & Shells & 0 & 5,495 & 45 \\
\hline 3 & APP10 175-180 cm & Shell & 0 & 5,125 & 35 \\
\hline 4 & APP10 $486 \mathrm{~cm}$ & Wood & -25 & 6,910 & 35 \\
\hline 5 & APP10 $502 \mathrm{~cm}$ & Wood & -25 & 7,020 & 35 \\
\hline 6 & APP16 94-96 cm & Shell & 0 & 1,465 & 35 \\
\hline 7 & APP16 $110 \mathrm{~cm}$ & Shells & 0 & 1,515 & 45 \\
\hline 8 & APP16 $420 \mathrm{~cm}$ & Shells & 0 & 40,470 & 1,020 \\
\hline 9 & APP16 464-465 cm & Shell & 0 & 54,200 & 2,800 \\
\hline 10 & APP17 $112 \mathrm{~cm}$ & Shell & 0 & 2,395 & 35 \\
\hline 11 & APP17 $460 \mathrm{~cm}$ & Shell & 0 & 43,070 & 720 \\
\hline 12 & APP18b $130 \mathrm{~cm}$ & Shells & 0 & 1,550 & 35 \\
\hline 13 & APP18b $150 \mathrm{~cm}$ & Shell & 0 & 2,990 & 30 \\
\hline 14 & APP18b 168-170 cm & Shells & 0 & 3,060 & 35 \\
\hline 15 & APP18b $260 \mathrm{~cm}$ & Shell & 0 & 5,530 & 35 \\
\hline 16 & APP18b $268 \mathrm{~cm}$ & Shells & 0 & 5,165 & 35 \\
\hline 17 & APP19 $120 \mathrm{~cm}$ & Shells & 0 & 1,965 & 35 \\
\hline 18 & APP19 $403 \mathrm{~cm}$ & Shells & 0 & 6,350 & 45 \\
\hline 19 & APP20 $185 \mathrm{~cm}$ & Shells & 0 & 4,110 & 35 \\
\hline 20 & APP20 547-557 cm & Wood & -25 & 47,000 & 1,200 \\
\hline 21 & APP22 71-73 cm & Shell & 0 & 1,260 & 35 \\
\hline 22 & APP22 73-75 cm & Shell & 0 & 900 & 30 \\
\hline 23 & APP22 $260 \mathrm{~cm}$ & Shells & 0 & 3,760 & 35 \\
\hline 24 & APP22 $487 \mathrm{~cm}$ & Wood & -25 & 8,325 & 35 \\
\hline 25 & APP23 $314 \mathrm{~cm}$ & Shells & 0 & 6,035 & 30 \\
\hline 26 & APP24 52-54 cm & Shell & 0 & 2,575 & 30 \\
\hline 27 & APP24 53-54 cm & Shells & 0 & 2,950 & 35 \\
\hline 28 & APP24 $246 \mathrm{~cm}$ & Shell & 0 & 2,565 & 40 \\
\hline 29 & APP24 $266 \mathrm{~cm}$ & Shells & 0 & 2,840 & 40 \\
\hline 30 & APP24 289-293cm & Shells & 0 & 4,875 & 35 \\
\hline 31 & APP24 322-327 cm & Shells & 0 & 3,420 & 35 \\
\hline 32 & APP24 325-327 cm & Shells & 0 & 5,005 & 45 \\
\hline 33 & APP24 335-336 cm & Shell & 0 & 5,380 & 30 \\
\hline 34 & APP24 $417 \mathrm{~cm}$ & Shells & 0 & 6,460 & 3 \\
\hline
\end{tabular}

identified using standard literature. Foraminiferal census data are reported elsewhere (Twichell et al. 2009).

\section{Results}

Biofacies analysis of eight cores

The benthic foraminifer assemblages along with characteristics of associated sediments were used to identify six depositional environments (Table 3 ) in eight cores from Apalachicola Bay. General sediment lithology and distri- bution of the six benthic biofacies are shown in Fig. 2. The six environments are normal marine, estuarine, marginal marine, deltaic, terrestrial, and barrier-island washover. Salinity of the normal-marine environment is estimated to be $33-37 \%$ with water depths of 3-30 $\mathrm{m}$, whereas the estuarine and marginal-marine environments represent gradationally lower salinities and shallower water depths.

A normal-marine environment is represented by predominately sandy sediments with a moderately diverse (Shannon-Wiener diversity index value $\mathrm{H}^{\prime}>2.2$ ) assemblage containing Miliolaceans (avg. of 27\%) and epiphytic foraminifers (avg. of 21\%; Twichell et al. 2009). Epiphytic species including Rosalina floridana and Rosalina floridensis live attached to sea grasses (Bock 1969). Therefore, these sediments indicate quiet, shallow water $(\sim 3-30 \mathrm{mwd})$

Table 3 Foraminiferal biofacies

\begin{tabular}{llll}
\hline Core & $\begin{array}{l}\text { Number of } \\
\text { samples }\end{array}$ & $\begin{array}{l}\text { Number } \\
\text { of species }\end{array}$ & Diversity $\left(\mathrm{H}^{\prime}\right)$ \\
\hline
\end{tabular}

\begin{tabular}{lrrl}
\hline $\begin{array}{l}\text { Normal-marine } \\
\text { AP07-16 }\end{array}$ & 3 & $12-23$ & $2.2-2.5$ \\
AP07-17 & 3 & $19-27$ & $2.4-2.6$ \\
Estuarine & & & \\
AP07-10 & 5 & $7-12$ & $1.4-2.0$ \\
AP07-16 & 4 & $6-8$ & $1.3-1.7$ \\
AP07-17 & 11 & $6-10$ & $1.1-1.9$ \\
AP07-18 & 11 & $9-16$ & $1.6-2.2$ \\
AP07-19 & 7 & $7-12$ & $1.5-2.0$ \\
AP07-20 & 6 & $9-13$ & $1.4-1.7$ \\
AP07-22 & 6 & $5-9$ & $1.3-1.8$ \\
AP07-24 & 15 & $6-11$ & $1.6-1.9$ \\
Deltaic & & & \\
AP07-10 & 4 & $0-8$ & $0-1.5$ \\
AP07-16 & 1 & 8 & 1.6 \\
AP07-17 & 3 & 0 & 0 \\
AP07-18 & 1 & 0 & 0 \\
AP07-20 & 1 & 2 & 0.4 \\
AP07-22 & 2 & 0 & 0 \\
AP07-24 & 1 & 7 & 1.56 \\
Marginal-m & & &
\end{tabular}

Marginal-marine

$\begin{array}{llll}\text { AP07-10 } & 2 & 1 & - \\ \text { Terrestrial } & & & \\ \text { AP07-10 } & 2 & 0 & 0 \\ \text { AP07-20 } & 2 & 0 & 0 \\ \text { AP07-22 } & 1 & 0 & 0 \\ \text { AP07-24 } & 3 & 0 & 0 \\ \text { Overwash } & & 7-8 & 1.7-1.8 \\ \text { AP07-18 } & 3 & 11 & 1.76 \\ \text { AP07-24 } & 1 & \end{array}$

$H^{\prime}=-\sum_{i=1}^{S} p_{i} \ln p_{i}$ 
Apalachicola Bay Vibracores 2007

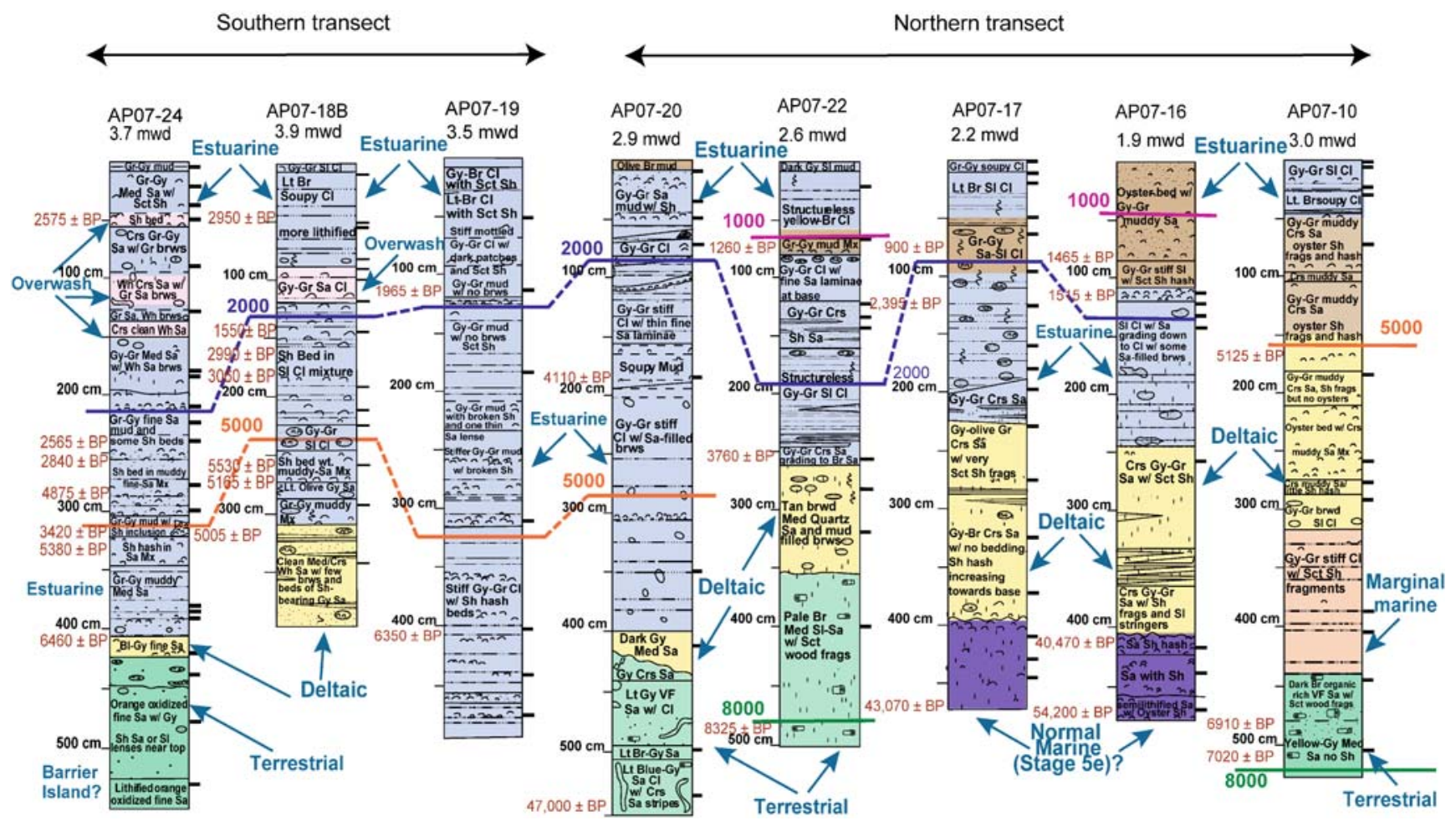

Fig. 2 Stratigraphic correlation of eight vibracores based on corelithology descriptions and microfossil analysis. Microfossil analysis has defined six biofacies (terrestrial, normal marine, estuarine, marginal marine, deltaic, and overwash). Core locations are found in Fig. 1. Bold black bars at the right side of core columns mark the locations of the microfossil samples. Uncorrected radiocarbon dates are shown in purple. $\mathrm{Sa}$ Sand, $\mathrm{Sl}$ silt, $\mathrm{Cl}$ clay, $\mathrm{Bl}$ blue, $\mathrm{Br}$ brown, $\mathrm{Gr}$ green, Gy gray, Wh white, Lt light, Med medium, Crs coarse, Mx matrix, Sh shell, Sct scattered, Brws burrows, w/ with, $V F$ very fine, frag fragments with a sandy bottom, reduced turbidity, and the presence of sea grass. Salinity is interpreted to be close to normal marine, with a location seaward of barrier islands. Infinite radiocarbon dates from shells in this facies, found at the bottom of cores AP07-16 and 17, place the age of this highstand deposit at possibly the last interglacial.

Silty and sandy muds containing a lower-diversity $\left(\mathrm{H}^{\prime} \sim 1.7\right)$ benthic foraminifer assemblage of euryhaline taxa characterize the estuarine facies. The estuarine assemblage is dominated $(50-90 \%)$ by the three calcareous species Ammonia parkensoniana, Ammonia veneta, and Elphidium excavatum, which are indicative of shallow water depths, variable salinity, and fluvial influence. Because agglutinated species occur rarely in this facies, and are found mostly near the tops of several cores, their absence may be taphonomic. Shell beds are also common in the estuarine facies. The nearabsence of shelf species, except as described in overwash sediments, indicates that there was restricted faunal and water exchange with the continental shelf. Additionally, the complete absence of epiphytic (sea grass-living) species implies that increased turbidity, rapid clastic sedimentation, or reduced salinity limited the occurrence of sea grass during deposition of these sediments. The estuarine facies is found in every core analyzed for microfossils. An estuarine depositional environment interpreted as occurring in $<10 \mathrm{mwd}$ and behind a barrier shoal or island system is consistent with the data.

Marginal-marine sediments were sampled in only one core, AP07-10. These silty-clay sediments contain marine shells, diatoms, abundant organic material, plant fragments, and Haplophragmoides sp., a coarse-grained agglutinated foraminifer, indicating very low salinity and very shallowwater coastal deposition.

Burrowed, muddy sands containing few mollusks and rare, sometimes abraded, shallow-water foraminifera or barren samples are defined as deltaic sediments. The depositional environment is interpreted as occurring in the delta plain and delta-front environments, and in some cases deltaic sediments are interbedded with estuarine sediments. Deltaic sediments are found in the lower portions of every core, except AP07-19.

Terrestrial sediments are predominately sand with silt and clay, and contain scattered wood fragments but no shells. Some examples of this facies contain burrows and layers of 
oxidized sediments. Wood-bearing terrestrial deposits with radiocarbon dates of $8,000-7,000{ }^{14} \mathrm{C}$ years B.P. were found in cores AP07-10 and 22, whereas the wood-bearing sediment in core AP07-20 yielded infinite dates, beyond the resolution of the radiocarbon dating method. The basal sediments of core AP07-24 consisted of well-oxidized orange sand with iron-cemented concretions, and no preserved terrestrial vegetation. However, this unit also contains partially dissolved and iron-stained benthic foraminifers that seem to identify several episodes of subaerial exposure.

Evidence of presumed barrier-island overwash is found in beds of white non-fossiliferous sand or thin sandy beds with rare numbers of transported shelf species, including Hanzawaia, and Cibicides. Both types of units are present within the estuarine muds in cores AP07-18 and 24, the two cores located closest to the barrier islands. Two radiocarbon dates on one sandy shell bed in AP07-24 $(51 \mathrm{~cm}$, Table 2) indicate reworked shells, which may provide evidence for a paleotempestite.

\section{Stratigraphic analysis of 16 cores}

The biofacies analyses shown on Fig. 2 were combined with basic lithologic descriptions of other cores from the bay and the high-resolution seismic data to construct two stratigraphic cross sections across the northern and southern portions of the bay (Fig. 3). The northern transect crosses two paleovalleys that converge into a single valley at the southern transect (Fig. 1). These valleys were identified on the seismic profiles, but were too deep to be sampled by our cores. One deep boring in the axis of the paleovalley collected at site MQ (Fig. 1) penetrated basal sandy bayhead delta deposits overlain by a fining-upward sequence (Schnable 1966). Only in the uppermost $3 \mathrm{~m}$ of the boring did the sand content increase again.

The early Holocene deposits that fill the paleovalleys nearly to their rims are too deep to be sampled by our cores as well. Coring could reach only the shallow interfluves adjacent to the valleys, where medium-to-coarse sands with shells (AP07-16, and 17) or wood fragments (AP07-10, 14, 20, 22, 23 , and 27) were recovered. The clean white-to-orange sand at the base of core AP07-24 is interpreted to be barrier-island or shoal deposits because of its non-fossiliferous nature, oxidation of sediment, and the absence of mud and wood (Fig. 2).

Our cores show that once the paleovalleys filled, sediment spread laterally across the entire bay (Fig. 3). The deposits that initially cover the fine-grained paleovalley fill and coarser-grained interfluve deposits are a mix of mud, muddy sand, and clean sand. The estuarine nature of the fauna in the fine-grained sediments (AP07-193 05, 07, 08, 09, 13, and 19) indicates that sheltered estuarine conditions began immediately once the bay began to flood. The widespread extent of the estuarine deposits suggests that a barrier-island or offshore shoal system was in place across the entire southern edge of the bay early in the history of sedimentation in the bay. Some of the sandy beds found interbedded with the estuarine sediments in the upper sections of cores AP0718 and 24 may be barrier-island overwash deposits.
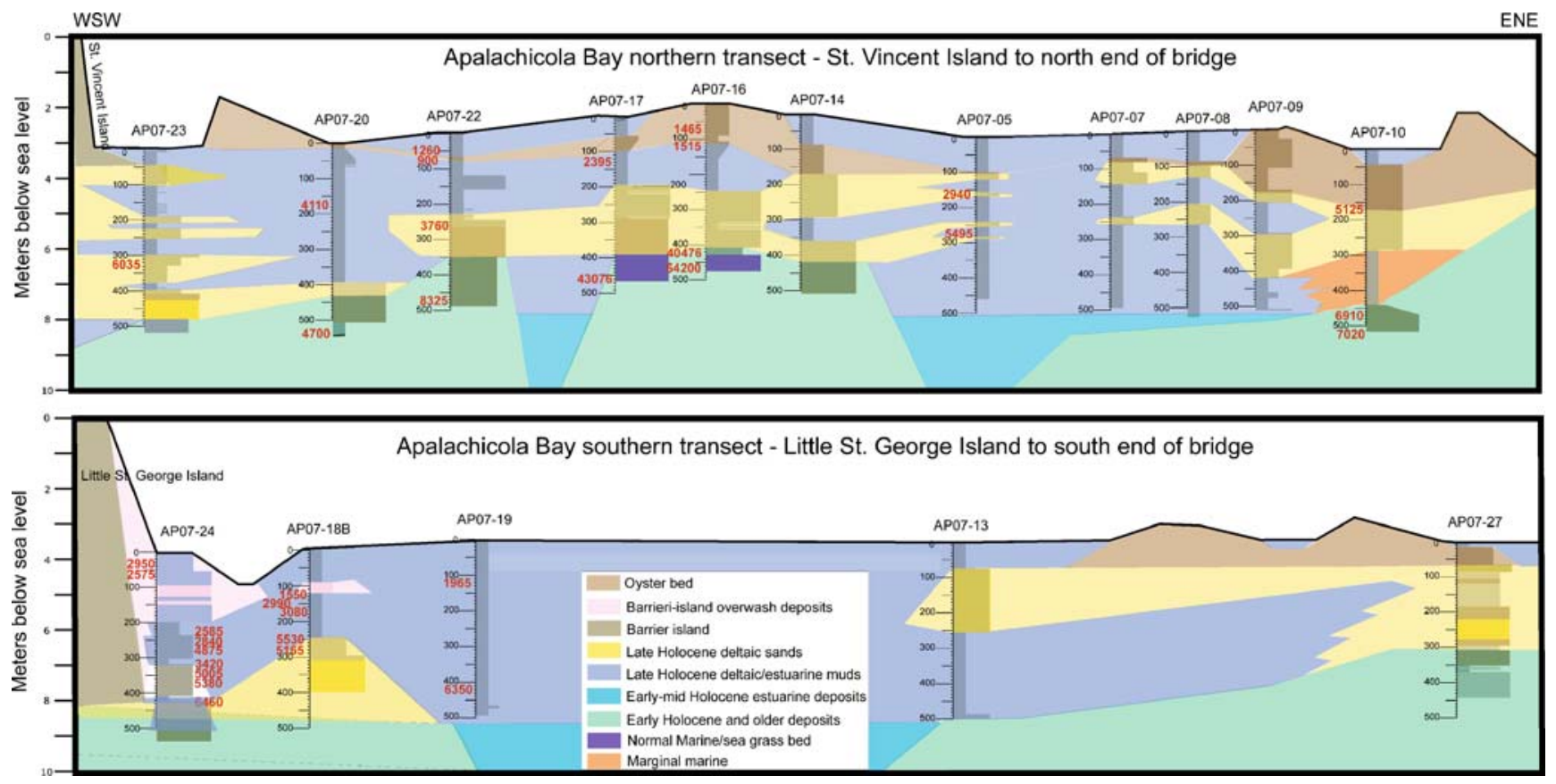

Fig. 3 Cross section showing the stratigraphic correlation based on high-resolution seismic profiles, core descriptions, grain-size analyses, and radiocarbon dating. Locations of the 16 cores on the northern and southern transects are shown in Fig. 1. Uncorrected radiocarbon dates are shown in red 
Other thick intervals of muddy sand devoid of marine or estuarine fauna are observed in many of the cores (Fig. 3), and are interpreted as the coarse components of delta systems. The top of the sandy-delta deposits coincides with high-amplitude reflections on seismic profiles, which were used to map the geographic extent of the deltaic deposits (Fig. 1). As the deltas advanced southward into the bay, behind the emerging barrier-island-shoal system, deltaic sands and prodelta mud accumulated in this estuarine setting (Fig. 3). Many of the cores show that once the
Fig. 4 a-h History of the Apalachicola Bay based on the results of this study focusing on the eight cores used for microfossil analysis. Figure part a contains the key for sedimentary environments recorded in the vibracores
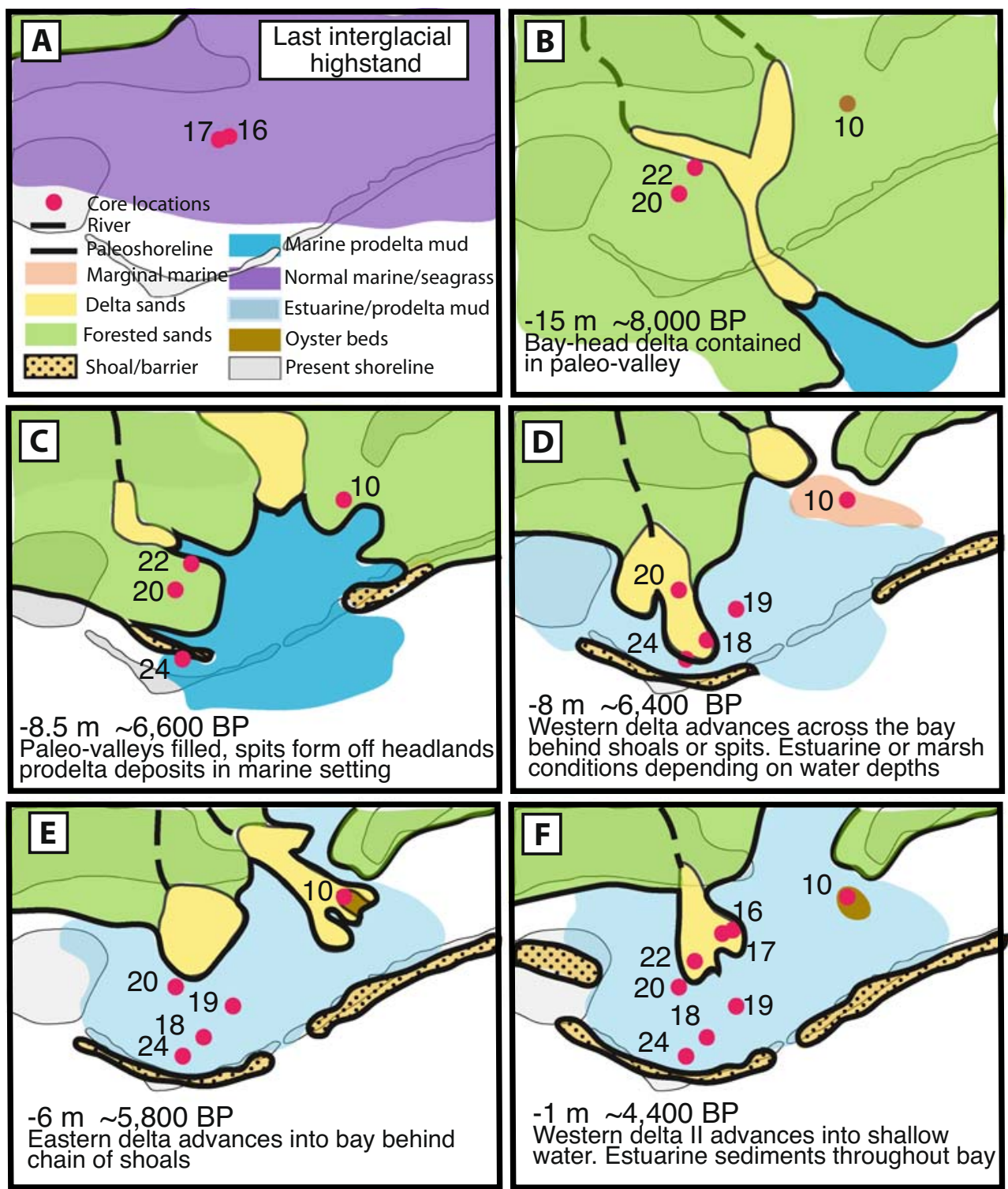

$-1 \mathrm{~m} \sim 4,400 \mathrm{BP}$

Western delta II advances into shallow water. Estuarine sediments throughout bay
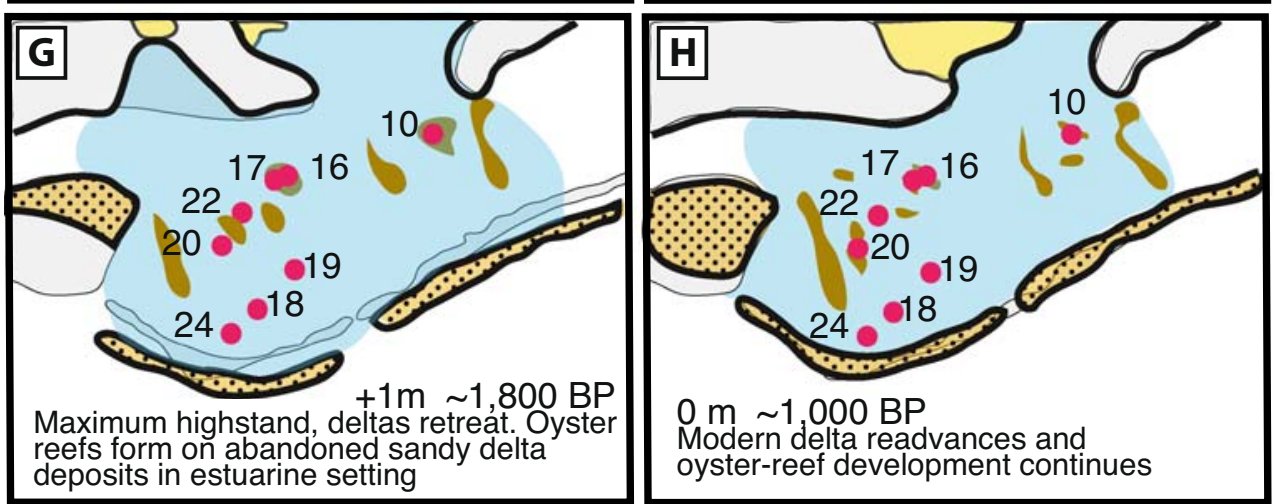

$0 \mathrm{~m} \sim 1,000 \mathrm{BP}$

Modern delta readvances and

oyster-reef development continues 
deltas were abandoned, the sandy parts were colonized by oysters (Fig. 3). The oyster beds have subsequently decreased in areal extent, due to burial by the continued influx of fine-grained sediment to the bay by the Apalachicola River.

\section{Discussion}

The combination of high-resolution seismic profiles and biofacies analyses with radiocarbon control enables the following reconstruction of the evolution of Apalachicola Bay (Fig. 4). Sea-level estimates are based on the history proposed by Balsillie and Donoghue (2004) for the Gulf of Mexico (Fig. 5). At the base of AP07-16 and 17, normalmarine conditions occur. These sediments, with infinite ${ }^{14} \mathrm{C}$ dates, are interpreted to represent a shelf environment that formed during the last interglacial highstand (Fig. 4a). The diverse fauna, which includes Miliolaceans and epiphytic (sea grass-living) forms, indicates a higher-than-present sea level with barrier islands absent or occurring landward of this location (Donoghue 1992). This was a quiet, sandy bottom with patches of sea grass. Following that highstand, sea level fell and the Apalachicola River incised paleovalleys that extended to the shelf edge (Donoghue 1993; McKeown et al. 2004).

During the sea-level lowstand, the exposed continental shelf was a terrestrial, vegetated coastal plain (Fig. 4b). Cores AP07-10, 20, and 22, to either side of the paleochannel where it crossed the present extent of Apalachicola Bay, contain abundant wood fragments with ${ }^{14} \mathrm{C}$ dates documenting forested areas at $8,000{ }^{14} \mathrm{C}$ years B.P. and earlier. As sea level rose following the last glacial maximum, fluvial deposits filled the Apalachicola River paleochannel, and bay-head deltas were deposited in the incised valleys off the mouth of the river (Fig. 4b).

As sea level rose to between 9 and 8 mbsl, coastal regions surrounding the paleovalleys were inundated, and the bay-head deltas continued to retreat landward (Fig. 4c). Preservation of wood-bearing sediments in cores AP07-10, 20 , and 22 indicates bay inundation was not yet extensive. Core AP07-24, which is farther offshore, contains clean white and orange sand with no foraminifers, which may be possible evidence for subaerial exposure perhaps indicating the initial formation of a barrier spit (Figs. 2 and 3).

Once the sea level reached $8 \mathrm{mbsl}$, much of the present bay was flooded (Figs. $4 d$ and 5). In core AP07-10, the encroaching shallow water deposited marginal-marine sediments containing agglutinated foraminifers and diatoms that overlie the wood-bearing sediments (Figs. 2 and 3). In the western part of the bay, deltaic sediments are found in cores AP07-18 and 20 (Figs. 2, 3 and 4d). In core AP07-24, a thin interval of deltaic sediment with a date of $6,460{ }^{14} \mathrm{C}$ years B.P. is overlain by estuarine sediment (Fig. 2). Finegrained estuarine sediments are found throughout AP07-19, indicating that this site was outside the influence of the sandy component of the deltas.

As sea level continued to rise to $6 \mathrm{mbsl}$ (Figs. 4e and 5), an eastern deltaic lobe advanced over older marginalmarine sediments in AP07-10. In the eastern core AP0710 , deltaic sediments with oyster shells continued to be deposited until shortly after $\sim 5,125{ }^{14} \mathrm{C}$ years (Table 2 ). In the western bay, estuarine sedimentation occurred landward of the barrier islands in cores AP07-18, 19, 20, and 24.

Radiocarbon-dated shells in deltaic sediments, found in cores AP07-16, 17, and 22, provide evidence for continued development of the western delta that may be associated with the fall in sea level beginning at $\sim 4,600{ }^{14} \mathrm{C}$ years B.P. (Balsillie and Donoghue 2004; Figs. 4f and 5). Radiocarbon-dated shells in estuarine sediments overlying the deltaic deposits indicate that progradation in the bay was ended $\sim 2,500{ }^{14} \mathrm{C}$ years B.P. Estuarine conditions are found throughout the bay after that time, but oysters are limited to the sandy deposits in the eastern part of the bay (AP07-10).

The highest post-glacial sea level is reported (Balsillie and Donoghue 2004) to have occurred at $\sim 1,800{ }^{14} \mathrm{C}$ years B.P.
Fig. 5 Gulf of Mexico sea-level curve from Balsillie and Donoghue (2004). Boxes labeled $\mathrm{C}-\mathrm{H}$ correspond to the figure parts in Fig. 4. Episodes of possible delta formation (yellow bars) based on radiocarbon dates (red stars) in the cores are shown at the bottom. Numbers on stars refer to the dates in Table 2. Estuarine sedimentation is shown with a blue bar. Maximum and minimum dates for the events are shown with associated arrows. All ages are uncalibrated

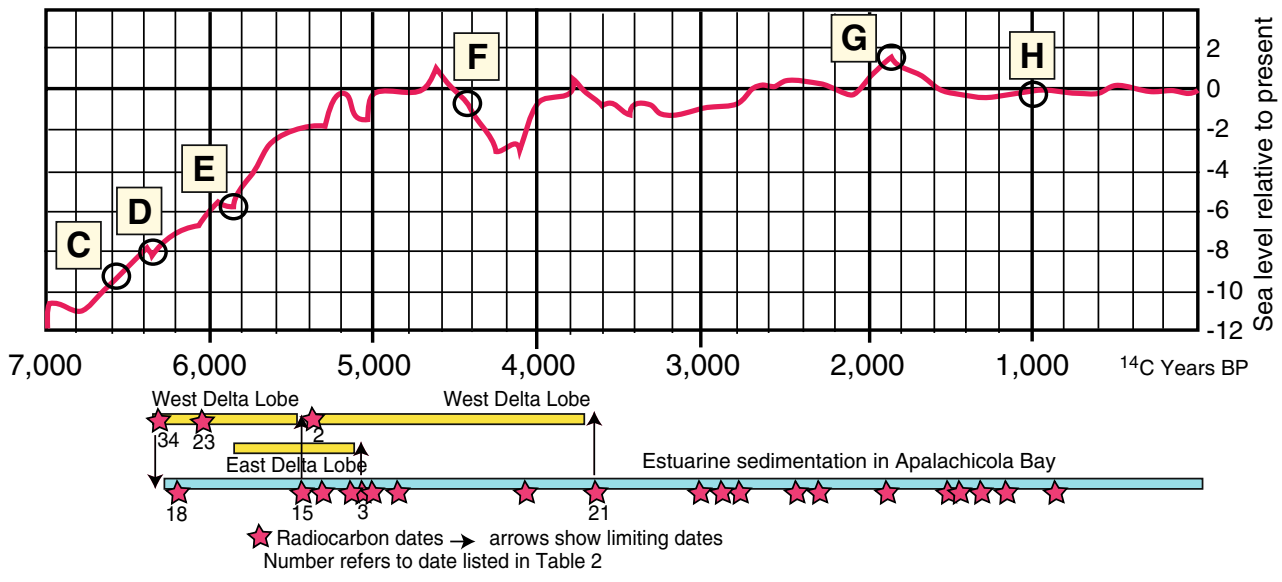


(Figs. $4 \mathrm{~g}$ and 5). At this time estuarine sediments are found in every core, and oyster beds are found in their maximum occurrence throughout the bay.

Modern sea-level conditions are established at $\sim 1,000$ ${ }^{14} \mathrm{C}$ years B.P. (Figs. $4 \mathrm{~h}$ and 5 ). Since then, the modern Apalachicola delta has been re-advancing into the bay, and the associated prodelta muds have blanketed some oyster beds and decreased their extent.

Timing and origin of the barrier islands

Radiocarbon dates indicate that the oldest beach strand on St. Vincent Island was fully formed by $4,500{ }^{14} \mathrm{C}$ years B.P. (Forrest 2007). However, two limiting radiocarbon dates from the AP cores indicate that shallow-water shoals may have been a feature restricting water circulation to the bay as early as $6,400{ }^{14} \mathrm{C}$ years B.P. (Table 2). A date of 6,350 ${ }^{14} \mathrm{C}$ years B.P. on shells from fine-grained sediment with estuarine fauna in $\mathrm{AP} 07-19$, and of $6,460{ }^{14} \mathrm{C}$ years B.P. on a thin bed of deltaic sediments in AP07-24 that is overlain by estuarine sediments provide evidence for the establishment of a fairly continuous offshore shoal that restricted the influx of normal-marine species into Apalachicola Bay by $\sim 6,400{ }^{14} \mathrm{C}$ years B.P.

The Apalachicola vibracore analyses indicate that both last interglacial (Fig. 4a) and exposed coastal-plain sediments (Fig. 4b) are predominately sand, and could have provided a sufficient quantity of sediments for the ultimate development of shoals and barrier islands. Culver et al. (2007) found that the position of the North Carolina Outer Banks barrier islands is related to a former topographic high. They propose that the initial formation of the Outer Banks occurred on the crest of a Pleistocene interstream divide as rising post-glacial sea level flooded the incised fluvial topography. Likewise, post-glacial marine transgression over the Apalachicola coastal-plain topographic highs could have led to the initial formation of shoals, and ultimately the barrier islands (Fig. 4c). The seismic and borehole measurements indicate that the Pleistocene surface on the Apalachicola shelf had considerable topography. Prior to the last marine transgression, topographic highs existed where parts of the barrier islands are found today ( $\sim 6$ to $9 \mathrm{mbsl}$ ), and topographic lows ( $\sim 6$ to $22 \mathrm{mbsl}$ ) occurred landward of the barrier islands (Florida Department of Transportation 1959, 1979, 1999; Schnable 1966; Otvos 1985). The timing of shoal formation is therefore indirectly inferred based on the establishment of estuarine conditions in Apalachicola Bay. The two limiting dates on estuarine sediments, $>6,350{ }^{14} \mathrm{C}$ years B.P. in AP07-19 and $<6,460$ ${ }^{14} \mathrm{C}$ years B.P. in $\mathrm{AP} 07-24$, provide evidence that circulation was restricted in the bay as early as $6,400{ }^{14} \mathrm{C}$ years $\mathrm{B}$. P. (Fig. 5).

\section{Conclusions}

This study indicates that development of estuarine conditions in Apalachicola Bay began in the early Holocene post-glacial transgression $\left(\sim 6,400{ }^{14} \mathrm{C}\right.$ years B.P.). Delta progradation into the Apalachicola Bay was a long continual process from before $6,460{ }^{14} \mathrm{C}$ years B.P. to after $2,940{ }^{14} \mathrm{C}$ years B.P., when sea level was between 8 and 1 mbsl lower than present. The advance of the deltas into the bay introduced a sandy substrate that provided the requisite habitat for subsequent oyster colonization. Oyster reefs are present before $5,125{ }^{14} \mathrm{C}$ years B.P. in core AP07-10 in eastern Apalachicola Bay, and appear to have colonized the western bay after $2,400{ }^{14} \mathrm{C}$ years B.P. Oyster beds had the greatest geographic distribution between $1,500-2,400{ }^{14} \mathrm{C}$ years B.P. Since $1,500{ }^{14} \mathrm{C}$ years B.P., the distribution of oyster beds has been decreasing in Apalachicola Bay.

Acknowledgements This research is indebted to many people. Thanks to Brian Andrews, Emile Bergeron, VeeAnn Cross, Bill Danforth, Jane Denny, Tom O'Brien, and Chuck Worley for help in collection and processing the seismic data, and to Jordan Sanford, Nick Ferina, and Julie Bernier for assistance with the vibracoring program in Apalachicola Bay. Don Hickey helped with sampling and photographing of the cores. We are grateful to Ashley Daigle and Kateland Merriweather for assistance in the lab and at the microscope, and Jennifer Flannery who aided with data interpretation. The manuscript benefited from constructive reviews by Joe Donoghue, Barbara Lidz, and an anonymous reviewer.

\section{References}

Balsillie JH, Donoghue JF (2004) High resolution sea-level history for the Gulf of Mexico since the last glacial maximum. Florida Geological Survey, Tallahassee Rep Investig no. 103

Bandy OL (1954) Distribution of some shallow water foraminifera in the Gulf of Mexico. Washington, DC, US Geol Surv Prof Pap 254-F:125-141

Bock WD (1969) Thalassia testudinum, a habitat and means of dispersal for shallow water benthonic foraminifera. Trans Gulf Coast Assoc Geol Soc 19:337-340

Culver SJ, Buzas MA (1983) Recent benthic foraminiferal provinces in the Gulf of Mexico. J Foram Res 13:21-31

Culver SJ, Grand Pre CA, Mallinson DJ et al (2007) Late Holocene barrier island collapse: Outer Banks, North Carolina, USA. Sediment Record 5:4-8

Donoghue JF (1992) Late Quaternary coastal and inner shelf stratigraphy, Apalachicola Delta region, Florida. Sediment Geol 80:293-304

Donoghue JF (1993) Late Wisconsinan and Holocene depositional history, northeastern Gulf of Mexico. Mar Geol 112:185-205

Donoghue JF, White NM (1995) Late Holocene sea-level change and delta migration, Apalachicola River region, northwest Florida, USA. J Coastal Res 11:651-663

Doyle LJ, Sparks TN (1980) Sediments of the Mississippi, Alabama, and Florida (MAFLA) continental shelf. J Sediment Res 50:905915

Florida Department of Transportation (1959) State road department, plans of proposed state highway, State Road No. 49580-3601. 
Eastpoint to St. George Island. Florida Department of Transportation, Tallahassee, FL

Florida Department of Transportation (1979) Project no. 49101-533. Apalachicola River Bridge on U.S. 98. Florida Department of Transportation, Tallahassee, FL

Florida Department of Transportation (1999) Report of core borings, financial project no. 218772-1-52-01. St. George Bridge-S.R. 300 over Apalachicola Bay. Florida Department of Transportation, Tallahassee, FL

Forrest BM (2007) Evolution of the beach ridge strandplain on St. Vincent Island, Florida. PhD Dissertation, Florida State University, Tallahassee, FL

López GI, Rink WJ (2008) New quartz optical stimulated luminescence ages for beach ridges on the St. Vincent Island Holocene strandplain, Florida, United States. J Coastal Res 24:49-62

McKeown HA, Bart PJ, Anderson JB (2004) High-resolution stratigraphy of a sandy, ramp-type margin-Apalachicola Bay, Florida, U.S.A. In: Anderson JB, Fillon RH (eds) Late Quaternary stratigraphic evolution of the northern Gulf of Mexico margin. Tulsa, OK, Soc Sediment Geol (SEPM) Spec Publ 79, pp 25-41

Osterman LE (2003) Benthic foraminifers from the continental shelf 405 and slope of the Gulf of Mexico: an indicator of shelf hypoxia. Estuar Coastal Shelf Sci 58:17-35

Otvos EG (1985) Barrier island genesis - questions of alternatives for the Apalachicola coast, northeastern Gulf of Mexico. J Coastal Res 1:267-278

Parker FL (1954) Distribution of the foraminifera in the northeastern Gulf of Mexico. Bull Mus Comp Zool 111:454-547

Phleger FB (1960) Sedimentary patterns of microfaunas in Northern Gulf of Mexico. In: Shephard FP, Phleger FB, van Andel TH (eds) Recent sediments, northwest Gulf of Mexico. American Association of Petroleum Geologists, Tulsa, pp 267-301

Phleger FB, Parker FL (1951) Ecology of foraminifera, northwest Gulf of Mexico. Part II. Foraminiferal species. Geol Soc Am Mem 46(2):1-64 Boulder, CO
Schnable J (1966) The evolution and development of part of the northwest Florida coast. PhD Dissertation, Florida State University, Tallahassee, FL

Schnable JE, Goodell HG (1968) Pleistocene-Recent stratigraphy, evolution and development of the Apalachicola coast, Florida. Boulder, CO, Geol Soc Am Spec Pap no 112

Stapor FW (1973) Coastal sand budgets and Holocene beach ridge plain development. PhD Dissertation, Florida State University, Tallahassee, FL

Stapor FW (1975) Holocene beach ridge plain development, northwest Florida. J Geomorphol 22:116-144

Twichell DC, Andrews BD, Edmiston L, Stevenson WR (2007) Geophysical mapping of oyster habitats in a shallow estuary: Apalachicola Bay, Florida. Woods Hole, MA, US Geol Surv Open-File Rep 2006-1381

Twichell DC, Pendelton EA, Poore RZ, Osterman LE, Kelso K (2009) Vibracore, radiocarbon, microfossil, and grain-size data from Apalachicola Bay Florida. Woods Hole, MA, US Geol Surv Open-File Rep 2009-1031

Whitfield WK, Beaumariage DS (1977) Shellfish management in Apalachicola Bay: past, present and future. In: Livingston RJ, Joyce EA (eds) Proc Conf The Apalachicola Drainage System, Florida Dept Nat Resources Mar Res Publ no 26, pp 130-140

\section{Faunal list}

Ammonia veneta (Schultze, 1854)

Ammonia parkinsoniana (d'Orbigny) = Rosalina parkensoniana d'Orbigny, 1939

Elphidium excavatum $($ Terquem) = Polystomella excavata Terquem, 1876

Rosalina floridana $($ Cushman $)=$ Discorbis floridanus Cushman, 1922

Rosalina floridensis (Cushman) $=$ Discorbis bertheloti var. floridensis Cushman, 1930 